\title{
Antioxidant, antimicrobial, haemolytic, germination and growth promoting properties of Crotalaria juncea $\mathrm{L}$.
}

\author{
Karl J Samuel P N ${ }^{1} \&$ Sornakumar R S A ${ }^{2^{*}}$ \\ ${ }^{1}$ Department of Biotechnology, Kamaraj College of Engineering and Technology, Madurai, Tamil Nadu, India \\ ${ }^{2}$ Department of Biotechnology, Jeppiar Engineering College, Chennai, Tamil Nadu, India \\ * Email: rsasornakumar2390@gmail.com
}

\section{ARTICLE HISTORY}

Received: 07 November 2019

Accepted: 16 February 2020

Published: 12 April 2020

\section{KEYWORDS}

antimicrobial activity; antioxidant

activity; Crotalaria juncea;

germination activity; growth

promotion; haemolytic activity

\section{ABSTRACT}

Crotalaria juncea L., commonly called as Sun Hemp generally found in tropical and sub-tropical regions of the Indian subcontinent, used as food and medicine by the tribal communities. The plant has been reported to have various medicinal properties. This study is focused on the evaluation of anti-oxidant, antimicrobial, haemolytic, germination and growth-promoting properties of $C$. juncea. The leaf and root extracts of the plant was prepared and used as the standard for various tests. The results obtained for the tests mentioned above were compared with each other. The crude proteins were found abundantly in the water extracts. The maximum antioxidant activity was found in the methanolic extracts of the leaf. It also showed a very little antimicrobial activity against Bacillus cereus and Bacillus subtilis. The germination and growth of the plant were significantly promoted by the methanolic extracts of the root when compared to the methanolic extract of the leaf. The extracts of the plant were found to have better growth-promoting activity. Crotalaria juncea can be incorporated in the fertilizers to promote the yield.

\section{Introduction}

Crotalaria juncea L. of family Fabaceae, commonly known as Sun Hemp found throughout tropical and sub-tropical regions of India, Nepal and Sri Lanka is a fiber crop used as food and medicine by tribal communities (1). It is a short, erect annual plant which grows to a height of 1-2.5 m with elongated leaves. The flowers are bell-shaped and yellow. The pods are cylindrical, short with a velvety texture which may contain up to 12 seeds (2).

The whole plant of $C$. juncea is also used as green manure in some areas of southern Tamil Nadu. $C$. juncea is used as a blood purifier, abortifacient, astringent, demulcent, emetic, purgative in the folk and Ayurvedic medicines and used for the treatment of anemia, impetigo, menorrhagia and psoriasis (1). The ethanolic extracts of $C$. juncea leaves have been found to have anti-inflammatory and anti-ulcerogenic activities (3). Ethanolic extracts of the whole plant of $C$. juncea was reported to have anti-hyper cholesteraemic activity (4). The seed oil of $C$. juncea contains a large amount of linoleic acid which is responsible for its anti-inflammatory and antibacterial activities (5). Seeds of $C$. juncea were found to have a notable anti-spermatogenic, anti-ovulatory and contraceptive activities (6-8).

Based on the traditional uses, this study focuses on the evaluation of the antioxidant, antimicrobial, haemolytic, germination and growth enhancement properties of Leaf and root extracts of $C$. juncea.

\section{Materials and Methods Preparation of sample}

Seeds of $C$. juncea were collected from the local seed shop, sown and grown in the virgin soil in P.S.R. Engineering College, Sivakasi, Tamil Nadu, India. The plant was confirmed by comparing with the herbarium sheets of "Queensland Herbarium" Accession number 664618. The plants of height $1.5 \mathrm{~m}$ were uprooted and the soil was removed by washing in running tap water. Leaves and roots were

(C) Samuel \& Sornakumar (2020). This is an open-access article distributed under the terms of the Creative Commons Attribution License, which permits unrestricted use, distribution, and reproduction in any medium, provided the original author and source are credited (https://creativecommons.org/licenses/by/4.0/).

To cite this article: Samuel P N K J, Sornakumar R S A. Antioxidant, antimicrobial, haemolytic, germination and growth promoting properties of Crotalaria juncea L. Plant Science Today. 2020;7(2):201-205. https://doi.org/10.14719/pst.2020.7.2.653 
separated, shade dried and powdered with the help of mortar and pestle.

\section{Preparation of extracts}

The powdered leaves and roots were weighed $10 \mathrm{~g}$ each separately and mixed with $20 \mathrm{ml}$ of water and methanol, respectively. The extraction was done using the maceration method. The mixture was left on a rotary shaker $(100 \mathrm{rpm})$ for $48 \mathrm{~h}$. The mixtures were then filtered using Whatman A1 filter paper and the filtrate was lyophilized obtain the powder form of the extract. $1 \mathrm{mg} / \mathrm{ml}$ solution of the extract was used as a stock solution for further studies.

\section{Total crude protein estimation}

Modified Lowry's Method (9) was used to determine the total crude protein present in the extracts. $0.5 \mathrm{ml}$ of the extract was made to $1 \mathrm{ml}$ using distilled water and then $2.5 \mathrm{ml}$ of Lowry's reagent was added. This mixture was incubated for $20 \mathrm{~min}$ at room temperature. $0.5 \mathrm{ml}$ of $1 \mathrm{~N}$ Folin's reagent was then added to the incubated mixture and this was again incubated for $10 \mathrm{~min}$ at $27^{\circ} \mathrm{C}$. The absorbance of the mixture was recorded at $650 \mathrm{~nm}$ and was compared with Bovine Serum Albumin Standard.

\section{Total free phenol estimation and hydroxyl free radical scavenging activity}

The overall antioxidant activity of the solution was determined by the Free phenol present in the solution. The total free phenol was estimated by modifying the Folin-Ciocalteau method (10). To $0.5 \mathrm{ml}$ of extract, $4 \mathrm{ml}$ of $1 \mathrm{M} \mathrm{Na}_{2} \mathrm{CO}_{3}$ and $0.5 \mathrm{ml}$ of $1 \mathrm{M}$ Folin's Reagent was added and incubated at $70{ }^{\circ} \mathrm{C}$ for $30 \mathrm{~min}$. The Absorbance was measured at $765 \mathrm{~nm}$ and the concentration of free phenol present in the extract was determined using Gallic Acid Standard.

Hydroxyl free radical scavenging activity was determined (11). To $1.5 \mathrm{ml}$ of extract, $20 \mu \mathrm{l}$ of $30 \%$ $\mathrm{H}_{2} \mathrm{O}_{2}$ was added and the absorbance was read at 230 $\mathrm{nm}$ for $60 \mathrm{~min}$ at an interval of $5 \mathrm{~min}$. Increasing scavenging ability is indicated by a decrease in absorbance.

\section{Antibacterial activity}

Agar well diffusion method was used to analyze the antibacterial activity of the extracts. The test strains (Pseudomonas fluorescens, Bacillus cereus, Bacillus subtilis and Escherichia coli) were swabbed over the surface of Nutrient Agar Plates. Sterile cork borer was used to punch wells and $100 \mu \mathrm{l}$ of the extracts (1 $\mathrm{mg} / \mathrm{ml}$ stock solution) were added into the wells. The plates were incubated at $37{ }^{\circ} \mathrm{C}$ for $24 \mathrm{~h}$ in an incubator. Zones of inhibition formed after the incubation period were measured.

\section{Haemolytic activity}

Sheep Blood was collected from the local slaughter house and centrifuged to separate the RBC. $0.5 \mathrm{ml}$ of sheep RBC and $0.5 \mathrm{ml}$ of yellow egg yolk were added to $50 \mathrm{ml}$ of $1 \%$ sterile Agar of $\mathrm{pH}$ 7.5. The Agar mixture was poured into sterile Petri plates and by using Sterile Cork Borer, wells were bored. To each well, $100 \mu \mathrm{l}$ of extracts were added and the plates were incubated at $37^{\circ} \mathrm{C}$ for $24 \mathrm{~h}$ in an incubator. The Haemolytic activity was determined by measuring the diameter of the pale yellow color zones formed around the well (12).

\section{Germination activity}

Green gram (Vigna radiata) seeds were collected from the local seed shop and soaked for $1 \mathrm{~h}$ in $10 \mathrm{ml}$ of $1 \mathrm{mg} / \mathrm{ml}$ extracts. Seeds soaked in sterile distilled water were used as Control. The sterile cotton bed was prepared on Petri plates. The soaked seeds were spread on the cotton bed and the bed was made wet by using respective solutions. Germination of the seeds was noted after $12 \mathrm{~h}$.

\section{Growth promoting activity}

$V$. radiata seeds were soaked for $1 \mathrm{~h}$ in $10 \mathrm{ml}$ of $1 \mathrm{mg} /$ ml extracts and sowed in the sterile soil on Petri plates. The plates were watered sufficiently with the respective solutions. The growth was measured every $24 \mathrm{~h}$ for five days $(120 \mathrm{~h})$. Seed soaked in distilled water was used as Control.

\section{Results and Discussion}

The results were obtained in quadruplets. Results were thus inferred by measuring standard deviation and mean of all the results. Microsoft Excel was used in compiling the results obtained manually.

\section{Total crude protein}

Total crude proteins in the Extracted samples were found using Lowry's method (Table 1). Among the extracts, Water extract of leaf contained more proteins about $0.39 \mu \mathrm{g} / \mathrm{ml}$ followed by the Water extract of the root which contains about $0.17 \mu \mathrm{g} / \mathrm{ml}$. The methanolic extracts have a low amount of proteins when compared to that of the water extracts. Methanolic extract of leaf and root contains about $0.12 \mu \mathrm{g} / \mathrm{ml}$ and $0.04 \mu \mathrm{g} / \mathrm{ml}$ respectively. Based on the results, the proteins are preserved in the water extracts rather than the methanolic extracts.

Table 1. Total crude proteins

\begin{tabular}{lc}
\hline Extract & $\begin{array}{c}\text { Total Proteins }(\boldsymbol{\mu g} / \mathbf{m l}) \\
\text { (BSA Standard) }\end{array}$ \\
\hline Leaf Methanol & $0.12 \pm 0.020$ \\
\hline Leaf Water & $0.39 \pm 0.030$ \\
\hline Root Methanol & $0.04 \pm 0.025$ \\
\hline Root Water & $0.17 \pm 0.015$ \\
\hline
\end{tabular}

Total free phenols and hydroxyl free radical scavenging activity

Free Phenols in the solution was estimated by the Folin-Ciocalteau method (Table 2). The water extract of root contained a large amount of free phenols of about $2.29 \mathrm{mg} / \mathrm{ml}$ which was followed by the methanolic extract of the root which contained about $2.12 \mathrm{mg} / \mathrm{ml}$. The Leaf extracts have a little less amount of phenols when compared to the root extracts. The water extract of leaf and methanolic extract of the leaf contains $1.67 \mathrm{mg} / \mathrm{ml}$ and $1.09 \mathrm{mg} / \mathrm{ml}$ of free phenols respectively.

The antioxidant property of the sample was determined by the Hydroxyl Free Radical Scavenging assay. The methanolic extract of root 
Table 2. Total free phenols

\begin{tabular}{lc}
\hline Extract & $\begin{array}{c}\text { Total Free Phenol(mg/ml) } \\
\text { (Galic Acid Standard) }\end{array}$ \\
\hline Leaf Methanol & $1.09 \pm 0.040$ \\
\hline Leaf Water & $1.67 \pm 0.030$ \\
\hline Root Methanol & $2.12 \pm 0.030$ \\
\hline Root Water & $2.29 \pm 0.035$ \\
\hline
\end{tabular}

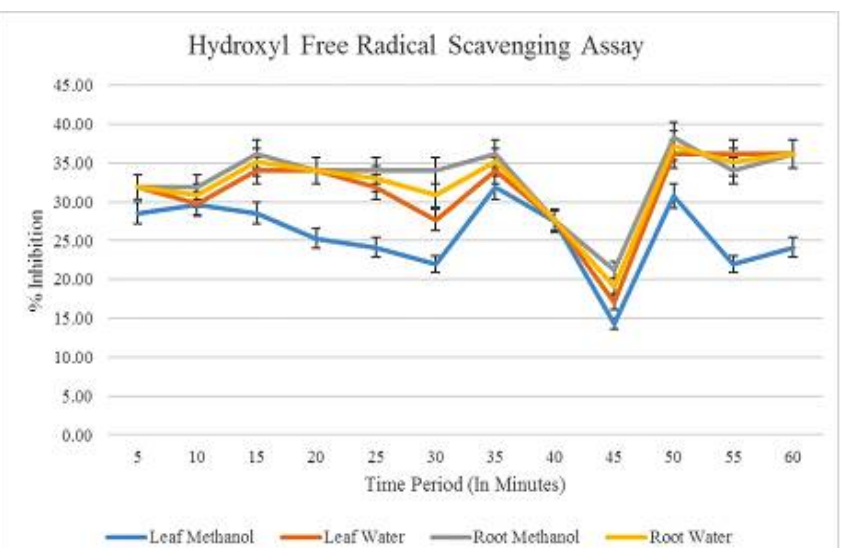

Fig. 1. Hydroxyl Free Radical Scavenging activity

showed a maximum scavenging activity of about $38.30 \%$. Water extract of root follows Methanolic extract of root with scavenging activity of approximately $37.23 \%$. Methanolic extract and water extract of leaf showed scavenging activity of about $31.87 \%$ and $36.17 \%$ respectively. The root extracts showed more scavenging activity when compared to the leaf extracts (Fig. 1).

It was also noted during our study that all the extract showed reduction in antioxidant activity at 45 minutes. This may be attributed to heating of the solution or the lamp which resulted in breakdown of $\mathrm{H}_{2} \mathrm{O}$ molecules. It may be also due to the complete depletion of scavenging molecules on the surface of the active component. The increase in scavenging activity obtained from 50 min can be due to structural rearrangement of the active component which further increased the release of $\mathrm{H}^{+}$ions into the solution for scavenging.

The antioxidant activity can be correlated to the presence of free phenols which enhances the redox reactions in the extract (13). Phenol groups in plant extracts scavenges free radicals by adsorbing and neutralizing them, quenching oxygen or decomposing peroxides (14).

\section{Antibacterial activity}

A minimum amount of antibacterial activity was found only for the methanolic extract of Leaf against $B$. cereus and $B$. subtilis (Table 3, Fig. 2). There was no antibacterial activity observed for the water extracts of both leaf and water and the methanolic extract of the root. The organisms such as $P$. fluorescens and E. coli showed resistance against all extracts. As the plant was used as green manure in some areas, this study implies that it was not toxic to the microorganisms present in the soil.
Table 3. Antibacterial activity

\begin{tabular}{lcccc}
\hline Organism & $\begin{array}{c}\text { Leaf } \\
\text { Methanol }\end{array}$ & $\begin{array}{c}\text { Leaf } \\
\text { Water }\end{array}$ & $\begin{array}{c}\text { Root } \\
\text { Methanol }\end{array}$ & $\begin{array}{c}\text { Root } \\
\text { Water }\end{array}$ \\
\hline $\begin{array}{l}\text { Pseudomonas } \\
\text { fluorescens }\end{array}$ & - & - & - & - \\
\hline Bacillus cereus & $0.15 \pm 0.05 \mathrm{~mm}$ & - & - & - \\
\hline Bacillus subtilis & $0.1 \pm 0.05 \mathrm{~mm}$ & - & - & - \\
\hline Escherichia coli & - & - & - & - \\
\hline
\end{tabular}
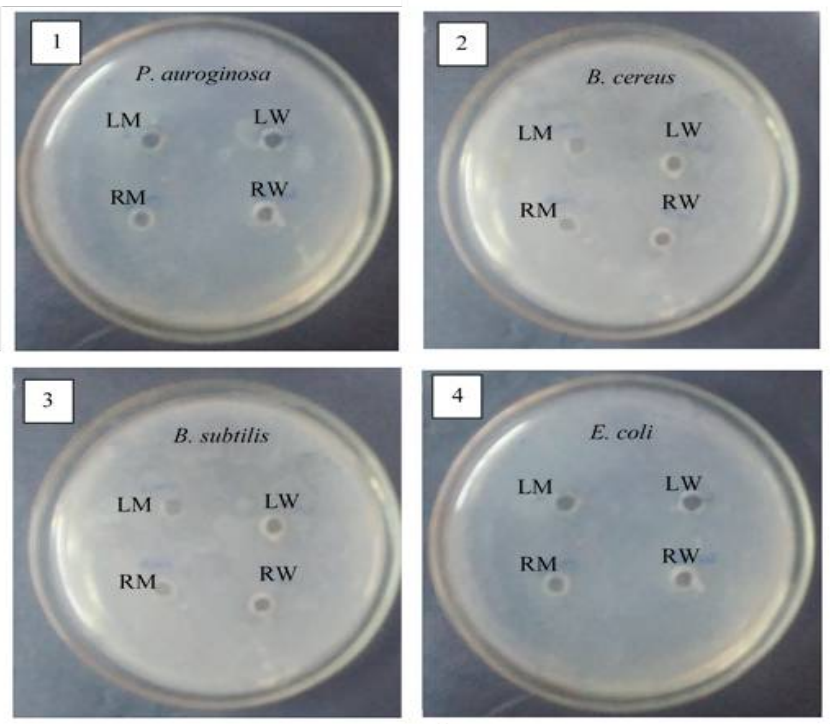

Fig. 2. Antimicrobial activity of leaf and root methanolic and water extracts.

\section{Haemolytic activity}

Haemolytic activity shows the toxicity of the substance to the haemocytes. There was no Haemolytic activity found for any of the samples (Fig. 3). This implies that all the extracts used in this experiment were safe to the haemocytes. There is no study on haemolytic efficiency of $C$. juncea as on date. Studies have shown that the haemolytic efficiency can be attributed to the presence of saponins. Saponins causes damage to cell wall and as a result the damages thus caused is not repairable and haemocytes are lysed $(13,15)$.

\section{Germination activity}

The Germination activity of the extracts was determined after $12 \mathrm{~h}$ of sowing the seeds (Table 4). Green Gram (Vigna radiata) seeds soaked in the methanolic extract showed $100 \%$ germinated. The water extract of leaf follows the activity of methanolic extract of water with $70 \%$ germinating activity. Water extract of the root has slightly more germinating activity (65\%) than the control used (60\%). The germination efficiency of leaf extract over control and root extract can be attributed to the accumulation of nitrogen in the leaves of $C$. juncea. Researches have inferred the increase in growth and yield due to higher accumulation of nitrogen in $C$. juncea (16). The results obtained didn't correlate much with the results obtained while estimating total protein present in the extract. Protein dissolves in water and get denatured in methanol. Wherein the germination enhancing activity is due to presence of other nitrogenous compounds which dissolves readily in methanol. 


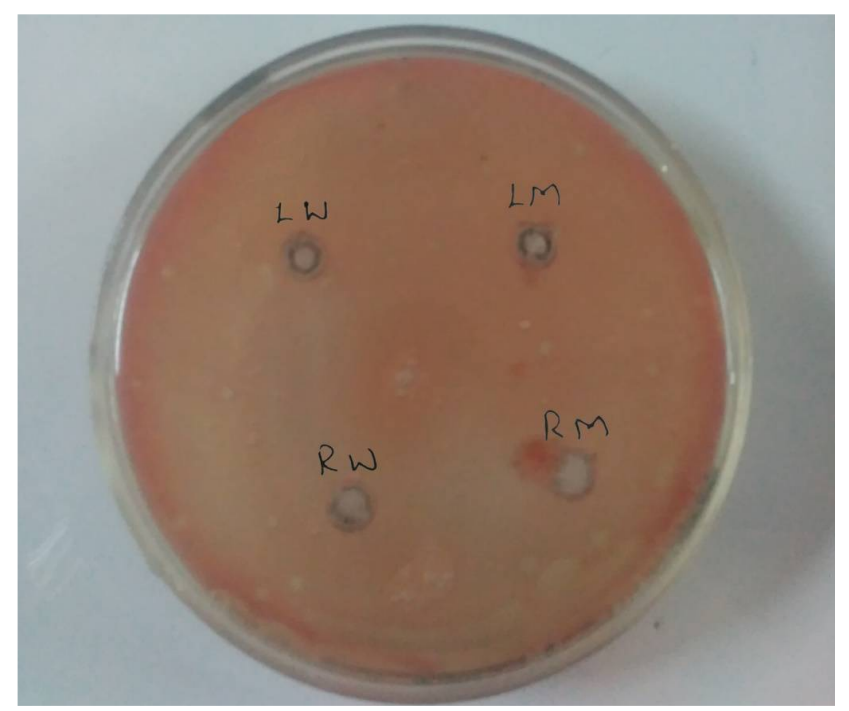

Fig. 3. Haemolytic activity of LW, LM, RW, RM on sheep RBC with no zones around the wells.

Table 4. Germination activity

\begin{tabular}{lccc}
\hline Sample & $\begin{array}{c}\text { Number of } \\
\text { seeds sown }\end{array}$ & $\begin{array}{c}\text { Number of seeds Percentage of } \\
\text { germinated }\end{array}$ & \begin{tabular}{c} 
Germination \\
\hline Control
\end{tabular} \\
\hline Leaf Methanol & 20 & 12 & $60 \%$ \\
\hline Leaf Water & 20 & 10 & $50 \%$ \\
\hline Root Methanol & 20 & 14 & $70 \%$ \\
\hline Root Water & 20 & 20 & $100 \%$ \\
\hline
\end{tabular}

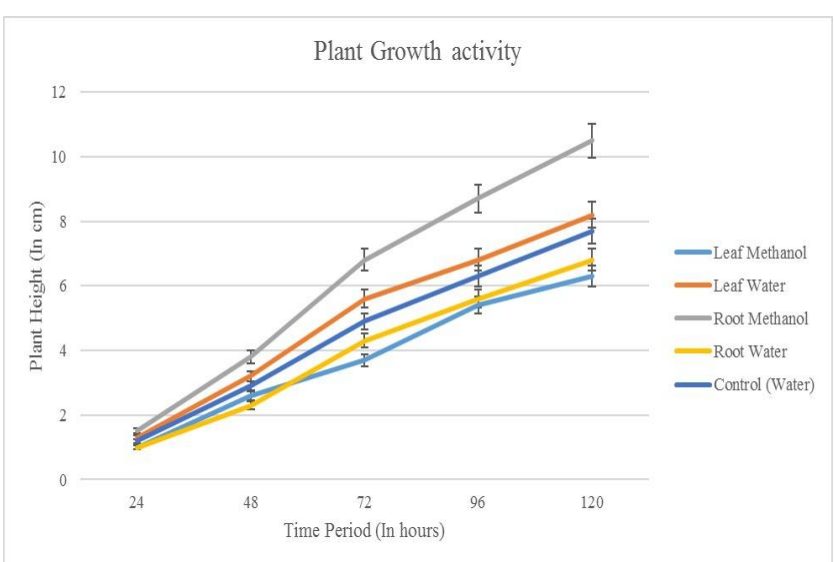

Fig. 4. Plant Growth promotion

\section{Growth promoting activity}

The growth of the Green gram (Vigna radiata) seeds soaked in respective $C$. juncea solutions were recorded for every $24 \mathrm{~h}$ for a total of $120 \mathrm{~h}$ (5 days). The seeds soaked in the methanolic extract of root showed maximum growth of about $10.5 \mathrm{~cm}$ in $120 \mathrm{~h}$. The seeds soaked in water extract of leaf showed a little more growth $(8.2 \mathrm{~cm}$ in $120 \mathrm{~h})$ than the control $(7.7 \mathrm{~cm}$ in $120 \mathrm{~h})$. The seeds soaked in water extract of root and methanolic extract of leaf showed about $6.8 \mathrm{~cm}$ and $6.3 \mathrm{~cm}$ in $120 \mathrm{~h}$. From the results of the study, the methanolic extract of root was found to be an excellent promoter of growth (Fig. 4). The growth promoting activity of $C$. juncea is attributed to its higher nitrogen accumulation and biological fixation in its parts (13). Based on the study it can be confirmed that accumulation of nitrogen is more in leaf extract when compared to root extract. This further justifies the traditional practice of ploughing the entire plant into the field.

\section{Conclusion}

The present study reveals that the extracts of the root have more antioxidant activity when compared to the extracts of the leaf. The antimicrobial activity was not found in the extracts, so they are safer for the native microorganisms of the soil. The Haemolytic activity is also not expressed by any of the extracts, so they can also be incorporated into medicines. The methanolic extract of the root is found to promote germination and growth when compared to that of other extracts. Further study is needed to isolate the compound that promotes growth and can be applied for better agricultural practices.

\section{Authors' contributions}

PNKJS has contributed to the collection of literature, carrying out the experimental part of the work and prepared the content of this manuscript. RSAS has contributed to the collection of literature, provided valuable inputs, planned the working methodology and supervised the work.

\section{Acknowledgements}

The authors are thankful to the Department of Biotechnology, P.S.R. Engineering College, Tamil Nadu, India for providing infrastructure facilities for carrying out this work.

\section{Conflict of interest}

Authors do not have any conflict of interest to declare.

\section{References}

1. Blume CL. Bijdragen tot de Flora van Nederlandsch Indie 14. Ter Lands Drukkerij, Batavia. 1826; pp. 781. http://dx.doi.org/10.5962/bhl.title.395

2. Mabberley DL. Mabberley's Plant-book. $4^{\text {th }}$ ed. Cambridge University Press, Cambridge, UK; 2017

3. Nees von Esenbeck CGD. Acanthaceae Indiae Orientalis. In: Wallich, N. (Ed.), Plantae Asiaticae rariores, vol. 3. Treuttel \& Wurtz,London, Paris \& Strasburg; 1832, pp. 75-76, 83, 98-99. https://www.biodiversitylibrary.org/item/9716

4. Bremekamp CEB. Materials for a monograph of the Strobilanthinae (Acanthaceae). Verhandelingen der Koninklijke Nederlandse Akademie van wetenschappen. Afdeling natuurkunde, Tweede Sect. 1944;41:1-305

5. Moylan EC, Bennett JR, Carine MA, Olmstead RG, Scotland RW Phylogenetic relationships among Strobilanthes s.1. (Acanthaceae): evidence from ITS nrDNA, TrnL-F cpDNA, and morphology. American Journal of Botany. 2004;91:724-35. https://doi.org/10.3732/ajb.91.5.724

6. Tripp EA, Daniel TF, Fatimah S, McDade LA. Phylogenetic Relationships within Ruellieae (Acanthaceae) and a Revised 
Classification. International Journal of Plant Sciences. 2013;174:97-137. http://www.jstor.org/stable/10.1086/668248

7. Deng YF, Wood JRI, Scotland RW. New and reassessed species of Strobilanthes (Acanthaceae) in the Flora of China. Botanica Journal of the Linnean Society. 2003;150:369-90. https://doi.org/10.1111/j.1095-8339.2006.00473.x

8. Carine MA, Alexander JM, Scotland RW. A revision of the Strobilanthes kunthiana-group (Phlebophyllum sensu Bremekamp) (Acanthaceae). Kew Bulletin. 2004;59:1-25

9. Wight R. Icones Plantarum Indiae Orientalis, vol. 4. JB Pharoah, Madras; 1849; pp. 19, t.1497. https://www.biodiversitylibrary.org/item/1859

10. Clarke CB. Acanthaceae. In: Hooker JD (ed.), Flora of British India, vol. 4. L. Reeve, London; 1884; pp. 435. http://www.biodiversitylibrary.org/bibliography/678

11. Wight R. Illustrations of Indian Botany vol. 2, American Mission Press, Madras; 1850; pp. 191, t.164b. https://www.biodiversitylibrary.org/item/39780
12. Anderson T. Acanthaceae. In: Thwaites GHK (ed.), Enumeratio Plantarum Zeylaniae. Dulau, London; 1864; pp. 223-26

13. Anderson T. An enumeration of the Indian species of Acanthaceae. The Journal of the Linnean Society, Botany. 1867;9:425-26. https://www.biodiversitylibrary.org/item/8360

14. Beddome RH. Icones Plantarum Indiae Orientalis, vol. 1. Gantz Brothers, Madras; 1874; pp. 53-54, t. 221 https://books.google.co.in/books?id=HKmEHAAACAAJ\&pg=PT23

15. Fyson PF. The Flora of the Nilgiri and Pulney Hill-Tops, vol. 1. The Superintendent, Govt. Press, Madras; 1915; pp. 312-13, t. 207. https://doi.org/10.5962/bhl.title.10798

16. Gamble JS. Flora of the Presidency of Madras, vol. 2. West, Newman \& Adlard, London; 1924; pp. 1025-44. https://www.biodiversitylibrary.org/item/10372 